\title{
Effect of Age on Outcome of High-Risk Non-Muscle-Invasive Bladder Cancer Patients Treated with Second Transurethral Resection and Maintenance Bacillus Calmette-Guerin Therapy
}

ikinci Transüretral Rezeksiyon Yapılan ve idame Bacillus CalmetteGuerin Tedavisi Alan Yüksek Riskli Kasa Invaze Olmayan Mesane Kanseri Hastalarının Sonuçlarına Yaşın Etkisi

\section{Sümer Baltacı1, Murat Bozlu2, Asıf Yıldııı33, Mehmet Illker Gökçe1, Illker Tinay4, Güven Aslan5,} Cavit Can6, Levent Türkeri4, Uğur Kuyumcuoğlu7, Aydın Mungan8

1 Ankara University Faculty of Medicine, Department of Urology, Ankara, Turkey

2 Mersin University Faculty of Medicine, Department of Urology, Mersin, Turkey

3 Medeniyet University Faculty of Medicine, Department of Urology, Istanbul, Turkey

4 Marmara University Faculty of Medicine, Department of Urology, Istanbul, Turkey

${ }^{5}$ Dokuz Eylül University Faculty of Medicine, Department of Urology, Izmir, Turkey

60 smangazi University Faculty of Medicine, Department of Urology, Eskişehir, Turkey

7 Trakya University Faculty of Medicine, Department of Urology, Edirne, Turkey

\&Bülent Ecevit University Faculty of Medicine, Department of Urology, Zonguldak, Turkey

\section{What's known on the subject? and What does the study add?}

High risk non-muscle invasive bladder cancer patients should be treated with maintenance Bacillus Calmette-Guerin (BCG) to obtain a reduce the risk of progression. The exact mechanism of action of BCG has not been clearly understood. However, there is clearly an action of immune system. Capacity of immune system decreases with advanced age and age has been shown to be associated with increased progression rates and decreased survival rates in patients receiving BCG. Previous studies are heterogeneous with respect to their population and they did not evaluate the effect of age on maintenance BCG response with the definition of progression involving Ta upstaging to T1.

\section{ABSTRACT}

Objective

To determine the effect of age on recurrence and progression rates in a population of high-risk non-muscle invasive bladder cancer (NMIBC) patients treated with a second transurethral resection (TUR) and at least 1 year of maintenance Bacillus Calmette-Guerin (BCG) therapy.

\section{Materials and Methods}

In this multicenter study, we reviewed the data of patients treated for high-risk NMIBC between 2005 and 2012. Patients without a muscleinvasive cancer on second TUR and received induction BCG and at least one year of maintenance BCG therapy and at least 12 months of follow-up after completion of maintenance BCG were included. Effect of age was analyzed both dichotomously ( $<70$ or $\geq 70$ years) as well as

\section{ÖZ}

Amaç

Bu çalışmada yüksek riskli kasa invaze olmayan mesane kanseri (KiOMK) nedeniyle ikinci transüretral rezeksiyon (TUR) yapılan ve idame Bacillus Calmette-Guerin (BCG) tedavisi alan hastalarda nüks ve progresyon oranlarına yaşın etkisinin değerlendirilmesi amaçlandı.

Gereç ve Yöntem

Bu çok merkezli çalışmada 2005-2012 yılları arasında yüksek riskli KiOMK nedeniyle tedavi edilen hastaların verileri incelendi. İkinci TUR da kasa invaziv olmayan, indüksiyon sonrası en az 1 yıl süre ile idame BCG tedavisi alan ve en az 12 ay tedavi alan hastalar dahil edildi. Yaşın etkisi hem iki grup olarak ( $<70$ vs $\geq 70$ yaş) hem de on yıllık artan gruplarda incelendi. Ki-kare, Student T-test ve ANOVA testi grupların karşılaştırılması için 
by 10-year increments. Chi-square test, Student's T-test and analysis of variance (ANOVA) were used for comparison of the groups. Univariate and multivariate logistic regression analyses were performed to identify predictors of recurrence and progression.

\section{Results}

Overall, 242 eligible patients were included. Baseline parameters were similar. With a mean follow-up of $29.4 \pm 22.2$ months, neither 3-year recurrence-free survival nor 3 -year progression-free survival differed between the age groups when examined either dichotomously or by $10-$ year increments.

\section{Conclusion}

In high-risk NMIBC patients treated with a second TUR and received maintenance BCG therapy, age was not associated with increased rates of neither recurrence nor progression. Until a randomized prospective clinical trial assess the appropriate adjuvant intravesical therapy in the elderly, elderly patients should probably be treated in the same manner as younger patients.

\section{Keywords}

Bacillus Calmette Guerin, age, nonmuscle-invasive bladder cancer, second transurethral resection kullanıldı. Nüks ve progresyonu öngören faktörlerin belirlenmesi için tek değişkenli ve çok değişkenli lojistik regresyon analizi uygulandı.

\section{Bulgular}

Çalışmada 242 hastanın verileri değerlendirildi. Yaş gruplarının temel özelliklerinde fark izlenmedi. Ortalama $29,4 \pm 22,2$ aylık takipte 3 yıllık nükssüz ve progresyonsuz sağkalım oranları açısından hem ikili grup hem de 10 yıllık artışlar ile yaş gruplanması ile fark saptanmadı.

\section{Sonuç}

İkinci TUR ve idame BCG ile tedavi edilen yüksek riskli KiOMK olgularında yaşın nüks ya da progresyon oranlarına etki etmediği görüldü. Ancak takip sürelerinin kısa olması nedeniyle fark gösterilememiş olabilir. Yaşlı hasta grubunda uygun intravezikal tedavinin belirleneceği bir randomize prospektif çalışma yapılana kadar yaşlı hastaların da büyük ihtimalle genç hastalar gibi tedavi edilmesi uygun olacaktır.

\section{Anahtar Kelimeler}

Bacillus Calmette Guerin, yaş, kasa invaze olmayan mesane kanseri, ikinci transüretral rezeksiyon

\section{Introduction}

Bladder cancer is the second most common malignancy of urinary system and non-muscle-invasive bladder cancer (NMIBC) accounting for about 75\% of the cases (1). High-risk NMIBC patients should be treated with intravesical Bacillus Calmette-Guerin (BCG) therapy including a maintenance schedule after a 6 weekly induction to obtain a reduction in the risk of progression. Another important aspect of treatment is performing a second transurethral resection (TUR) performed within 2-6 weeks after initial resection to decrease the recurrence and progression rates $(2,3,4)$.

The exact mechanism of action of BCG has not been clearly understood. However, detection of immune cells in the bladder wall and cytokines in urine clarifies the action of immune system (5). However, the capacity of immune system decreases with advanced age and age has been shown to be a parameter associated with increased progression rates and decreased survival rates in patients receiving $B C G(6,7,8)$.

In the above mentioned trials, the study populations are heterogeneous as two important factors, maintenance BCG and a second TUR, were not performed in all patients $(6,7,8)$. Besides, in these trials, progression was defined as upstaging to T2 or higher or presence of metastatic disease $(6,7,8)$. However, in NMIBC, progression of Ta disease to T1 disease has been shown to be important (9) and the International Bladder Cancer Group involved progression of Ta disease to T1 disease in the definition of progression (10).

To our knowledge, there is no clinical trial evaluating the effect of age on response to maintenance BCG with the definition of progression involving Ta upstaging to T1. In this retrospective multicenter trial, we aimed to identify the effect of age on recurrence and progression rates in a population with high-risk NMIBC treated with maintenance BCG therapy.

\section{Materials and Methods}

The study was planned and performed by the Association of Urooncology of Turkey bladder cancer study group. Retrospective data of patients, who were treated for high-risk NMIBC between 2005 and 2012 and received induction BCG and at least one year of maintenance BCG, were collected from ten participating centers.

Patients were included if;

1) A high grade Ta or any T1 urothelial carcinoma with or without carcinoma in situ (CIS) was present in the first TUR specimen,

2) A complete first TUR (reported by the surgeon to be complete resection) of bladder carcinoma and a second TUR were performed,

3) Received 6 weekly instillations of BCG therapy and at least 1 year of maintenance BCG therapy,

4) At least 12 months of follow-up after completion of maintenance BCG.

Patients with a histology other than pure urothelial carcinoma (urothelial carcinoma together with other histologic variants were also excluded), incomplete resection at initial TUR, a diagnosis of muscle invasive cancer on second TUR, a time interval of $>90$ days between first and second TUR, and those who did not complete 1 year of maintenance therapy were excluded. During the second TUR, aggressive resection of all visible and suspected tumors with adequate sampling of muscle layer was performed. The patients were assessed with cystoscopy, cytology and tumor resection every 3 months for the first 2 years and then biannually for a minimum of 5 years and annually thereafter as indicated. Progression was defined as an increase in pathological stage ( $\mathrm{Ta}$ to $\mathrm{T} 1$ or $\mathrm{T} 1$ to $\geq \mathrm{T} 2$ ).

Individual patient data were requested for the following patient and tumor characteristics and were included in the database: age, gender, tumor grade, T stage, concomitant $\mathrm{CIS}$, primary or recurrent 
tumor, number of tumors, main tumor size, application of early single dose intravesical chemotherapy, recurrence, and progression. Central pathological review of the specimens was not performed.

Association of age with recurrence-free survival (RFS) and progressionfree survival PFS) rates was the primary outcome measure of the study. Effect of age was analyzed both dichotomously $(<70$ or $\geq 70$ years) as well as by 10 -year increments $(<50,50-59,60-69, \geq 70$ years $)$ with regard to previous trials $(6,11)$. Cox univariate and multivariate proportional hazards regression models were fit with end points, time to recurrence and time to progression.

\section{Statistical Analysis}

Statistical analysis was performed using SPSS v. 20.0. A Chi-square test was used to compare categorical variables and student's t-test and analysis of variance were applied for continuous variables of the groups based on time to second TUR. Univariate and multivariate logistic regression analyses were performed to identify predictors of recurrence and progression. Kaplan-Meier curves were constructed for RFS and PFS and the groups were compared with the log-rank test. A $p$ value of less than 0.05 was considered statistically significant.

\section{Results}

Out of 264 retrospectively evaluated patients, a total of 242 patients fulfilled the inclusion criteria. Twenty-two patients were excluded; 13 due to incomplete initial TUR, 6 for elapsed time $>90$ days between first and second TUR, 2 for having histology other than urothelial cancer and 1 due to a short follow-up ( $<6$ months) period after completion of BCG. The mean age of study population was $64.7 \pm 10.7$ years and the mean follow-up period was $29.4 \pm 22.2$ months (range 12-96) without a significant difference between the groups. Of the patients, 212 (87.6 $\%)$ were male and 30 (12.4\%) were female. Stage Ta and T1 tumors were present in 40 (16.5\%) and 202 (83.5\%) patients, respectively. Concomitant CIS was present in 19 patients. High-grade tumors were present in 214 (88.4\%) patients and immediate postoperative singledose intravesical chemotherapeutic instillation was given to 162 (66.9\%) patients. Pathological evaluation of the surgical specimens of the second TUR revealed NMIBC in 104 (42.9\%) patients.

Regarding the age groups, there were 150 patients $<70$ years of age and 92 patients $\geq 70$ years of age. The number of patients in age groups $<50,50-59,60-69$, and $\geq 70$ years was 20,49, 81, and 92 respectively. There were no differences between the groups in age, sex, T stage, concomitant CIS, tumor grade, largest tumor diameter, tumor multiplicity, tumor status (primary, recurrent) or instillation of immediate postoperative intravesical chemotherapy (all $p$ values $=>0.05$ ) (Table 1 ).

\section{Survival Analysis}

The 3-year RFS rates were $63.3 \%, 68.1 \%, 68.1 \%$ and $59.7 \%$ in age groups of $<50,50-59,60-69$, and $\geq 70$ years, respectively $(p=0.701$, Figure 1a). When age groups of $<70$ years and $\geq 70$ years were compared, RFS rates were $81.9 \%$ and $72.8 \%$, respectively $(p=0.257$, Figure 1b).

The 3-year PFS rates were $80.0 \%, 87.7 \%, 83.1 \%$ and $77.5 \%$ in age groups of $<50,50-59,60-69$, and $\geq 70$ years, respectively $(p=0.393$, Figure 2a). No significant difference was observed between the age groups $<70$ years and $\geq 70$ years in terms of PFS (PFS: $94.4 \%$ vs $86.3 \%$, $p=0.100$, Figure $2 b)$. On univariate analysis, tumor grade [(odds ratio $(\mathrm{OR})]$ 3.107, 95\% confidence interval (Cl) 1.724-7.918, $p=0.0008$ ) and concomitant CIS (OR 1.933, 95\% Cl 1.302-5.267, $p=0.001)$ were found to be associated with a higher risk of recurrence (Table 2). Tumor grade (OR 2.221, 95\% Cl 1.488-6.178, $p=0.002$ ) was the only factor identified as predictor of progression on univariate analysis (Table 3 ).

Table 1. Baseline patient characteristics by age groups

\begin{tabular}{|c|c|c|c|c|c|c|c|c|}
\hline Variables & $\begin{array}{l}<50 \text { years } \\
n=20\end{array}$ & $\begin{array}{l}50-59 \\
\text { years } \\
n=49\end{array}$ & $\begin{array}{l}60-69 \text { years } \\
n=81\end{array}$ & $\begin{array}{l}\geq 70 \text { years } \\
n=92\end{array}$ & $p$ value & $\begin{array}{l}<70 \text { years } \\
n=150\end{array}$ & $\begin{array}{l}\geq 70 \text { years } \\
n=92\end{array}$ & $p$ value \\
\hline \multicolumn{9}{|l|}{ Sex } \\
\hline Male, n (\%) & $18(90)$ & $39(79.6)$ & $71(87.7)$ & $82(89.1)$ & \multirow{2}{*}{0.680} & $128(85.3)$ & $82(89.1)$ & \multirow{2}{*}{0.397} \\
\hline Female, n (\%) & $2(10)$ & $10(20.4)$ & $10(12.3)$ & $10(10.9)$ & & $22(14.7)$ & $10(10.9)$ & \\
\hline \multicolumn{9}{|l|}{ Stage } \\
\hline $\mathrm{Ta}, \mathrm{n}(\%)$ & $2(10)$ & $7(14.3)$ & $13(16.0)$ & $18(19.6)$ & \multirow{2}{*}{0.551} & $22(14.7)$ & $18(19.6)$ & \multirow{2}{*}{0.319} \\
\hline $\mathrm{T} 1, \mathrm{n}(\%)$ & $18(90)$ & $42(85.7)$ & 68 (84.0) & $74(80.4)$ & & $128(85.3)$ & 74 (80.4) & \\
\hline High grade tumor, $n(\%)$ & $17(85.0)$ & $42(85.7)$ & 74 (87.6) & $81(88.0)$ & 0.481 & $133(88.7)$ & $81(88.0)$ & 0.883 \\
\hline Concomitant $\mathrm{CIS}, \mathrm{n}(\%)$ & $2(10)$ & $4(8.2)$ & $6(7.4)$ & $7(7.6)$ & 0.229 & $12(8.0)$ & $7(7.6)$ & 0.912 \\
\hline Tumor size, mean \pm SD & $2.69 \pm 1.3$ & $2.56 \pm 1.2$ & $2.73 \pm 1.2$ & $2.66 \pm 1.3$ & 0.644 & $2.67 \pm 1.3$ & $2.66 \pm 1.3$ & 0.905 \\
\hline Patients with multiple tumors, n (\%) & $5(25)$ & $14(28.6)$ & $24(29.6)$ & $30(32.6)$ & 0,900 & $43(28.7)$ & $30(32.6)$ & 0.516 \\
\hline Patients with primary tumors, $\mathrm{n}(\%)$ & $17(85.0)$ & $43(87.7)$ & $67(82.7)$ & $80(86.9)$ & 0.449 & $127(84.7)$ & $80(86.9)$ & 0.623 \\
\hline $\begin{array}{l}\text { Immediate postoperative intravesical } \\
\text { chemotherapy, } \mathrm{n}(\%)\end{array}$ & $12(60)$ & $31(63.2)$ & $52(64.2)$ & $57(61.9)$ & 0.598 & 95 (63.3) & $57(61.9)$ & 0.829 \\
\hline
\end{tabular}


On multivariate analysis, tumor grade (OR 2.533, 95\% Cl 1.1215.822, $p=0.003$ ), and concomitant CIS (OR 1.534, 95\% Cl 1.078-2.544, $p=0.008$ ) were detected as predictors of recurrence.

\section{Discussion}

Treatment of high-risk NMIBC is of importance as the disease has a significant potential of progression. The current practice involves performance of a second TUR and application of maintenance BCG. Verification of prognostic factors for response to maintenance BCG is important to detect patients that must be followed closely to not lose the chance of more aggressive treatments in case of progression. Patients with progression to muscle invasive disease from a NMIBC have unfavorable prognosis even after radical cystectomy (12).

Prognostic factors for this patient population has recently been investigated $(6,7)$. In the study of European Organisation for Research and Treatment of Cancer (EORTC) 30911, data of patients undergoing maintenance BCG have been evaluated. The authors evaluated the value of age as a prognostic factor and accepted 70 years of age as the cut of value. Age was not found to be a predictor of recurrence,

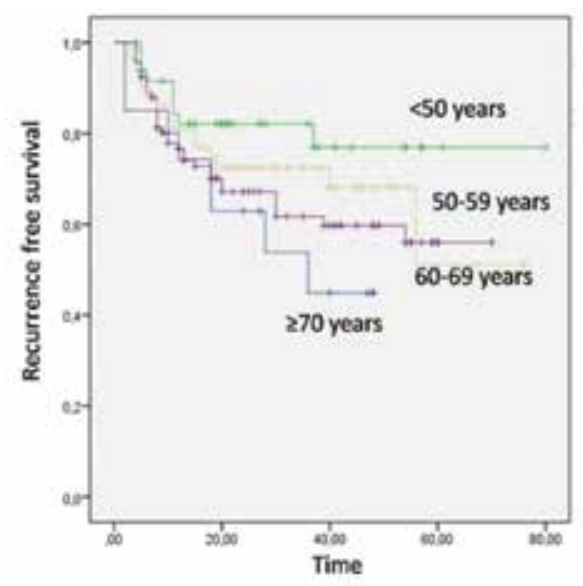

Figure 1. Kaplan-Meier curves of the recurrence free survival rates for the groups according to 4 groups

Kaplan-Meier curves of the recurrence free survival rates for the groups according to 2 groups however, patients older than 70 years of age were found to have a shorter time to progression as well as shorter overall and cancerspecific survival rates. The authors mentioned the reduced activity of immune system by age as the cause of poorer survival rates and higher risk of progression (6). In that study, the authors did not mention any information on performing a second TUR in their population, a factor which is associated with decreased recurrence and progression rates as well as better response to BCG $(13,14)$. In our study, all patients similarly received maintenance $B C G$, besides, all patients underwent a second TUR.

Another important point is the definition of progression. In the EORTC 30911 study, progression was defined as muscle invasion or distant metastasis. However, the International Bladder Cancer Group defined progression as: an increase in T stage from CIS or Ta to T1 (lamina propria invasion); development of $\geq T 2$ or lymph node $\left(\mathrm{N}_{+}\right)$ disease or distant metastasis (M1); or an increase in grade from low to high, and concluded that Investigators should consider the use of this new definition to help standardize protocols and improve the

\begin{tabular}{|c|c|c|c|}
\hline Variables & OR & $95 \% \mathrm{Cl}$ & $p$ value \\
\hline Age ( $<70$ years vs $\geq 70$ years) & 1.007 & $0.326-1.174$ & 0.997 \\
\hline Age (regarding 4 groups) & 1.002 & $0.297-1.228$ & 0.998 \\
\hline Sex & 1.127 & $0.485-1.777$ & 0.866 \\
\hline Stage (Ta vs T1) & 1.218 & $0.687-1.792$ & 0.708 \\
\hline Grade (high vs low) & 2.221 & $1.488-6.178$ & 0.002 \\
\hline Concomitant $\mathrm{CIS}$ & 1.286 & 0.703-2.114 & 0.662 \\
\hline Tumor size & 1.215 & $0.617-1.887$ & 0.694 \\
\hline $\begin{array}{l}\text { Tumor focality (solitary vs } \\
\text { multiple) }\end{array}$ & 1.116 & $0.471-1.684$ & 0.905 \\
\hline $\begin{array}{l}\text { Tumor status (primary vs } \\
\text { recurrent) }\end{array}$ & 1.187 & $0.606-1.903$ & 0.601 \\
\hline $\begin{array}{l}\text { Immediate postoperative } \\
\text { intravesical chemotherapy }\end{array}$ & 1.147 & $0.551-1.874$ & 0.667 \\
\hline \multicolumn{4}{|c|}{ CI: Confidence interval, OR: Odds ratio, CIS: Carcinoma in situ } \\
\hline
\end{tabular}

\section{Table 2. Univariate analysis for detection of predictors for recurrence}

\begin{tabular}{|l|l|l|l|}
\hline Variables & $\mathrm{OR}$ & $95 \% \mathrm{Cl}$ & $\mathrm{p}$ value \\
\hline Age (<70 years vs $\geq 70$ years) & 1.011 & $0.455-1.396$ & 0.844 \\
\hline Age (regarding 4 groups) & 1.003 & $0.341-1.228$ & 0.954 \\
\hline Sex & 1.147 & $0.692-2.189$ & 0.814 \\
\hline Stage (Ta vs T1) & 1.209 & $0.780-2.802$ & 0.428 \\
\hline Grade (low vs high) & 3.107 & $1.724-7.918$ & 0.0008 \\
\hline Concomitant CIS & 1.933 & $1.302-5.267$ & 0.001 \\
\hline Tumor size & 1.325 & $0.856-2.887$ & 0.308 \\
\hline Tumor focality (solitary vs multiple) & 1.165 & $0.498-1.942$ & 0.738 \\
\hline Tumor status (primary vs recurrent) & 1.225 & $0.597-2.867$ & 0.318 \\
\hline Immediate postoperative intravesical chemotherapy & 1.366 & $0.603-2.955$ & 0.299 \\
\hline Cl: Confidence interval, OR: Odds ratio, CIS: Carcinoma in situ & & \\
\hline
\end{tabular}




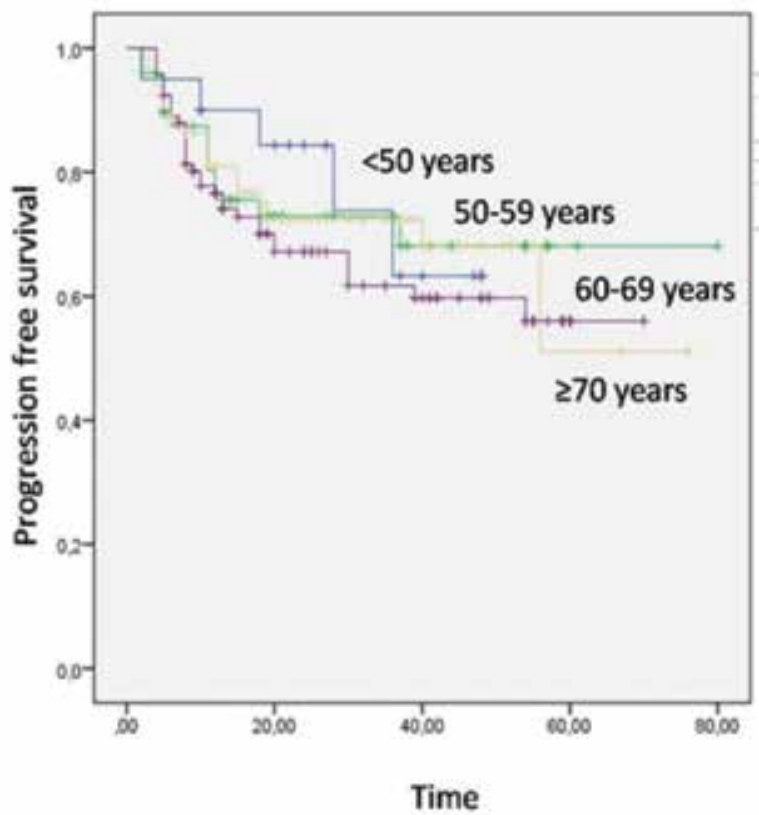

Figure 2a. Kaplan-Meier curves of the progression free survival rates for the groups according to 4 groups

reporting of progression (10). Our study is the first study investigating prognostic factors for recurrence and progression in high-risk NMIBC patients receiving maintenance BCG together with the definition of progression involving progression of Ta to T1 stage but not low-grade to high-grade disease.

In another study on the highest number of T1G3 patients, prognostic factors were evaluated to define risk groups. In that study Restaging TUR prior to BCG was performed in only $38.2 \%$ of patients and maintenance BCG was given to only another $38.2 \%$ of patients (7). Besides, progression was defined as progression to muscle-invasive disease. The results of multivariate analysis revealed that maintenance BCG and tumor size were the factors associated with increased recurrence and progression rates and decreased overall and cancerspecific survival rates. Additionally, age ( $\geq 70$ years) was associated with increased progression rates and decreased overall and cancerspecific survival rates.

In our study, effect of age on recurrence and progression rates was evaluated and age (both categorically and as a continuous variable) was not found to be associated with increased recurrence and survival rates. There are important differences between our study and the previous cohorts. Our cohort involved patients who underwent a second TUR and received maintenance BCG therapy. In addition, in our study, the definition of progression involved progression from Ta to T1 disease as suggested by the International Bladder Cancer Group. RFS and PFS rates in the $\geq 70$ years group were slightly lower compared to that in the $<70$ years group, however, this difference did not reach statistical significance (RFS: $72.8 \%$ vs. $81.9 \%$ and PFS: $86.3 \%$ vs $94.4 \%$ ). This may be associated with the definition of progression and other properties of the population, however, more importantly, our cohort had a relatively lower duration of follow-up and also due to lower number of patients, power of the current study may not be sufficient to detect an underlying significant difference.

Concomitant CIS was found to be an important prognostic parameter

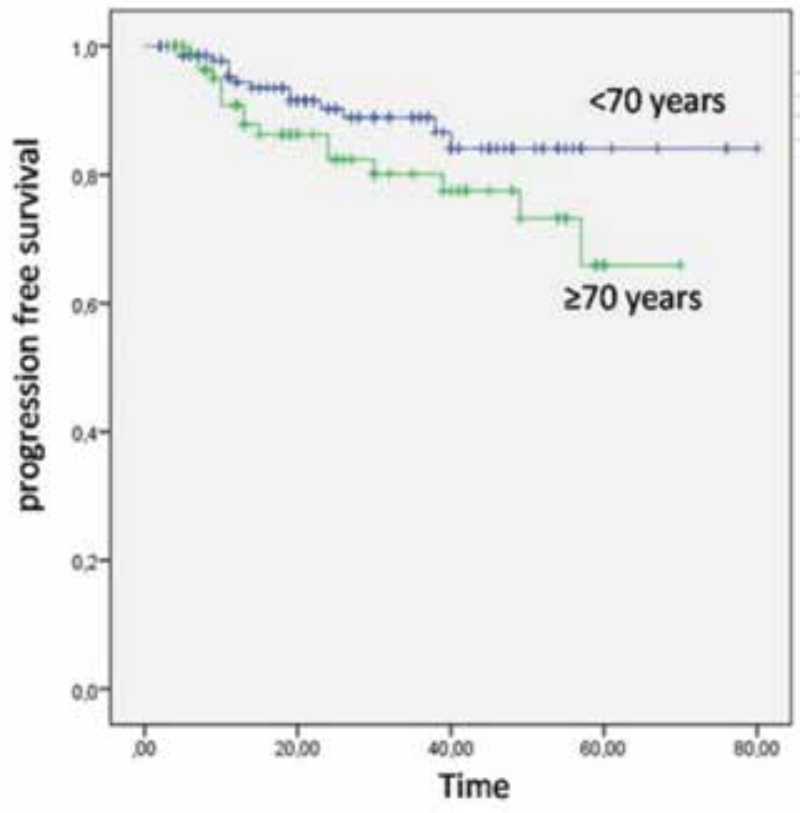

Figure 2 b. Kaplan-Meier curves of the progression free survival rates for the groups according to 2 groups

in a previous study (15) and it was found to be associated with increased recurrence rates in our study. It was observed to be associated with increased progression but not with increased recurrence rates in a study by Gontero et al. (7). Tumor grade was the only parameter associated with higher progression rates in our series.

This study is limited by its retrospective nature. The patients were included from 10 different centers and therefore quality of TUR was probably variable. However, this aspect represents the real life much better. In addition, although the sample size of 242 patients may be insufficient to provide desirable power level, our data includes relatively homogeneous patient population consisting of high-risk NMIBC patients and all underwent second TUR and were treated with a maintenance BCG. Therefore, cautious use of these findings is recommended in patients who receive only induction BCG after second TUR. Additionally, central pathological review was not performed and this may affect especially the tumor grade results of the patients.

\section{Conclusions}

In high-risk NMIBC patients treated with a second TUR and received maintenance BCG, age was not found to be associated with increased rates of neither recurrence nor progression. However, the duration of follow-up was short and a significant difference has not been found. Prospective randomized studies with longer follow-up are needed to validate the effect of age on the rates of response to BCG with the definition of progression involving Ta to T1 progression.

\section{Acknowledgement}

The study is conducted by Turkish Society of Urooncology. We would like to thank Dr. Talha Müezzinoğlu and Dr. Cihat Özcan for contribution to the study.

\section{Ethics}

Ethics Committee Approval: The study was performed retrospectively and ethical committe approval was not done, Informed Consent: 
Informed consent has been received from all of the patients prior to surgery.

Peer-review: External and internal peer-reviewed.

\section{Authorship Contributions}

Surgical and Medical Practices: Sümer Baltacl, Murat Bozlu, Levent Türkeri, Mehmet İlker Gökçe, Cavit Can, Aydın Mungan, Güven Aslan, Asıf Yıldırım, Uğur Kuyumcuoğlu, İlker Tinay, Concept: Sümer Baltacı, Levent Türkeri, Cavit Can, Aydın Mungan, Güven Aslan, Design: Sümer Baltacı, Levent Türkeri, Cavit Can, Aydın Mungan, Güven Aslan, Data Collection or Processing: Mehmet İlker Gökçe, Asıf Yıldırım, Uğur Kuyumcuoğlu, Analysis or Interpretation: Sümer Baltacı, Mehmet Illker Gökçe, Literature Search: Sümer Baltacı, Mehmet Ilker Gökçe, Aydın Mungan, Writing: Sümer Baltacı, Levent Türkeri, Mehmet IIker Gökçe.

Conflict of Interest: No conflict of interest was declared by the authors.

Financial Disclosure: The authors declared that this study has received no financial support.

\section{References}

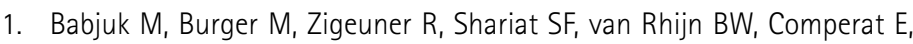
Sylvester RJ, Kaasinen E, Bohle A, Palou Redorta J, Roupret M, European Association of $U$. EAU guidelines on non-muscle-invasive urothelial carcinoma of the bladder: update 2013. Eur Urol 2013;64:639-653.

2. Sfakianos JP, Kim PH, Hakimi AA, Herr HW. The effect of restaging transurethral resection on recurrence and progression rates in patients with nonmuscle invasive bladder cancer treated with intravesical bacillus Calmette-Guerin. J Urol 2014;191:341-345.

3. Dobruch J, Borowka A, Herr HW. Clinical value of transurethral second resection of bladder tumor: systematic review. Urology 2014;84:881-885.

4. Divrik RT, Sahin AF, Yildirim U, Altok M, Zorlu F. Impact of routine second transurethral resection on the long-term outcome of patients with newly diagnosed PT1 urothelial carcinoma with respect to recurrence, progression rate, and disease-specific survival: a prospective randomised clinical trial. Eur Urol 2010;58:185-190.

5. De Boer EC, De Jong WH, Steerenberg PA, Aarden LA, Tetteroo E, De Groot $E R$, Van der Meijden AP, Vegt PD, Debruyne FM, Ruitenberg EJ. Induction of urinary interleukin-1 (IL-1), IL-2, IL-6, and tumour necrosis factor during intravesical immunotherapy with bacillus Calmette-Guerin in superficial bladder cancer. Cancer Immunol Immunother 1992;34:306312.

6. Oddens JR, Sylvester RJ, Brausi MA, Kirkels WJ, van de Beek $C_{\text {, van }}$ Andel $G$, de Reijke TM, Prescott $S$, Witjes JA, Oosterlinck W. The effect of age on the efficacy of maintenance bacillus Calmette-Guerin relative to maintenance epirubicin in patients with stage Ta $\mathrm{T} 1$ urothelial bladder cancer: results from EORTC genito-urinary group study 30911. Eur Urol 2014;66:694-701.

7. Gontero $P$, Sylvester $R$, Pisano $F$, Joniau $S$, Vander Eeckt $K$, Serretta $V$, Larre S, Di Stasi S, Van Rhijn B, Witjes AJ, Grotenhuis AJ, Kiemeney LA, Colombo R, Briganti $A$, Babjuk M, Malmstrom PU, Oderda $M$, Irani J, Malats N, Baniel J, Mano R, Cai T, Cha EK, Ardelt P, Varkarakis J, Bartoletti R, Spahn M, Johansson R, Frea B, Soukup V, Xylinas E, Dalbagni G, Karnes $R J$, Shariat SF, Palou J. Prognostic factors and risk groups in T1G3 nonmuscle-invasive bladder cancer patients initially treated with Bacillus Calmette-Guerin: results of a retrospective multicenter study of 2451 patients. Eur Urol 2015;67:74-82.

8. Fernandez-Gomez J, Solsona E, Unda M, Martinez-Pineiro L, Gonzalez M, Hernandez R, Madero R, Ojea A, Pertusa C, Rodriguez-Molina J, Camacho JE, Isorna S, Rabadan M, Astobieta A, Montesinos M, Muntanola P, Gimeno A, Blas M, Martinez-Pineiro JA, Club Urologico Espanol de Tratamiento 0. Prognostic factors in patients with non-muscle-invasive bladder cancer treated with bacillus Calmette-Guerin: multivariate analysis of data from four randomized CUETO trials. Eur Urol 2008;53:992-1001.

9. Sfakianos JP, Kim PH, Hakimi AA, Herr HW. The effect of restaging transurethral resection on recurrence and progression rates in patients with nonmuscle invasive bladder cancer treated with intravesical bacillus Calmette-Guerin. J Urol 2014;191:341-345.

10. Lamm D, Persad R, Brausi M, Buckley R, Witjes JA, Palou J, Bohle A, Kamat $\mathrm{AM}$, Colombel $\mathrm{M}$, Soloway $\mathrm{M}$. Defining progression in nonmuscle invasive bladder cancer: it is time for a new, standard definition. J Urol 2014;191:20-27.

11. Margel D, Alkhateeb SS, Finelli A, Fleshner N. Diminished efficacy of Bacille Calmette-Guerin among elderly patients with nonmuscle invasive bladder cancer. Urology 2011;78:848-854.

12. van den Bosch $S$, Alfred Witjes J. Long-term cancer-specific survival in patients with high-risk, non-muscle-invasive bladder cancer and tumour progression: a systematic review. Eur Urol 2011;60:493-500.

13. Grimm MO, Steinhoff $C$, Simon $X$, Spiegelhalder $P$, Ackermann $R$, Vogeli TA. Effect of routine repeat transurethral resection for superficial bladder cancer: a long-term observational study. J Urol 2003;170:433-437.

14. Divrik RT, Yildirim U, Zorlu F, Ozen $H$. The effect of repeat transurethral resection on recurrence and progression rates in patients with $\mathrm{T} 1$ tumors of the bladder who received intravesical mitomycin: a prospective, randomized clinical trial. J Urol 2006;175:1641-1644.

15. Herr HW, Dalbagni G, Donat SM. Bacillus Calmette-Guerin without maintenance therapy for high-risk non-muscle-invasive bladder cancer. Eur Urol 2011;60:32-36. 